\title{
Construction of Heat Recovery Generation System for Co-generation in Commercial and Residential Sectors \\ - Improvement of Scroll Shapes for High-power and High-performance in Scroll Steam Expander -
}

\author{
Shogo ISHII ${ }^{* 1}$, Soichiro IKEGAMI ${ }^{*}$, Hiroshi TERAO $* 1$, Taisuke ONO*2, \\ Yasuyuki HAMACHI ${ }^{* 2}$, Kyoji INAOKA *3, Jiro SENDA *3, and Mamoru SENDA*3 \\ (Received March 12, 2010)
}

\section{民生用コージェネレーションを対象とした排熱回収発電システムの構築 一スクロール形状の改良によるスクロール蒸気膨張機の高出力・高性能化一}

石井翔伍 ${ }^{* 1}$, 池上聡一郎*1, 寺尾 紘*1, 小野泰右 ${ }^{* 2}$, 演地康之 ${ }^{* 2}$, 稲岡恭二*3, 千田二郎*3, 千田 衞*3

This study is intended to develop the waste heat recovery generation system using steam-Rankine cycle for co-generation system with a small capacity prime mover in the range of about $500 \mathrm{~kW}$ or less. In our previous reports, a scroll expander has attracted attention as a power recovery device which has high efficiency potential even in the case of small power capacity, and the performance characteristics of it are investigated through the experiments. Then, it was confirmed that the leakage loss at the beginning of expansion process and the thermal loss cause the performance of the scroll expander to decrease. Therefore, in this paper, the shape of the orbiting scroll was redesigned to prevent the leakage, and also the type of the scroll expander was changed from symmetric scroll to asymmetric scroll which had high expansion ratio for high-power and high-performance. As a result, the expander performance was improved by the reduction of the leakage and the increase of the net power, and the expander efficiency reached up to $60.8 \%$ at the maximum under the experimental conditions that the suction pressure of working fluid was $590 \mathrm{kPa}$ and the revolution speed was $1950 \mathrm{rpm}$.

\section{Key Words}

Cogeneration system, Waste heat recovery, Rankine cycle, steam, Scroll expander, Asymmetric scroll

\section{1. 緒 言}

エネルギ有効利用技術の一つとして，電気と熱を同時供給 できるコージェネレーションシステム (CGS) が注目されてお り，今後の普及にも大きな期待が寄せられている。近年のCGS の動向として, エネルギ需要の大きい産業分野だけでなく, 省 エネ意識の高まっている事業所や家庭など民生分野への導入 が拡大している11。しかし，小口需要である民生分野では，原

* 1 Department of Mechanical Engineering, Graduate School of Doshisha University 1-3, Miyakodani, Tatara, Kyotanabe, Kyoto 610-0321, Japan

* 2 YANMAR Co., Ltd. 1600-4, Umegahara, Maibara, Shiga 521-8511, Japan

* 3 Faculty of Science and Engineering, Doshisha University 1-3, Miyakodani, Tatara, Kyotanabe, Kyoto 610-0321, Japan
動機の小容量化に伴う発電効率の低下や熱需要の減少する中 間期における排熱利用率の低下といった問題が生じる。これ により年間を通して総合エネルギ効率を高い状態で維持でき ず，CGSの優位性が発揮できていない状況にある2)。今後，民 生用CGSの有効性をより高めるためには, 原動機排熱の利用 方法および排熱回収機器の効果的利用が重要となる。

この課題に対し，本研究では民生分野における発電容量500

$* 1$ 同志社大学大学院工学研究科機械工学専攻 干 610-0321 京都府京田辺市多々羅都谷 1-3

* 2 ヤンマー(株) 于 521-8511 滋賀県米原市梅ヶ原 1600-4

* 3 同志社大学理工学部 干 610-0321 京都府京田辺市多々羅都谷 1-3 
$\mathrm{kW}$ 以下の中・小規模のCGSを対象とし, 水蒸気ランキンサイ クルを用いた排熱回収発電システムの構築を目指している ${ }^{3)}$ 。 過去の研究において，筆者らはシステムの回収出力に最も影 響を与える動力回収機として小容量でも高効率を誇るスク ロール膨張機 4) 5) に着目し，その性能特性の基礎的解明を行 なった6)。その結果，膨張過程初期に発生する最内室から外側 膨張室への内部漏れが膨張機効率を低下させる主因であると の知見を得た。また同時に，漏れを抑制するだけでは一定容 積の膨張機に投入される水蒸気流量も減少するため, 膨張機 の出力低下を招くことも実験的に判明した。

そこで，本研究では作動流体に飽和水蒸気を用いたスク ロール膨張機の高性能化を目的に, 膨張過程初期に生じる内 部漏れの低減を図ると同時に膨張機の高出力化を試みた。ま ず漏れ対策としては，スクロール歯形の中央部における形状 を改良することで内部漏れが生じにくい構造とした。スク ロール形状の変更に関する研究は圧縮機7 8), 膨張機9) ともに 報告されているが，本研究はいずれの手法とも異なる。歯形 改良の効果は，改良前後における膨張機内の圧力変化や膨張 機効率，膨張過程で生じる損失を比較することで検証した。

膨張機の高出力化手法としては, 従来の対称型スクロール 膨張機よりも高膨張比となる非対称スクロール 10) 11) が有効と 考えられるが，膨張機に適用した場合の実験的研究は見当た らない。そのため, 本研究では非対称スクロール膨張機を試 作し，その性能試験および対称型との比較・検証を行なった。

\section{2. 実験装置}

\section{1 スクロール膨張機の作動原理}

スクロール膨張機は作動流体を膨張させることで動力を得 る容積形の流体機械である。ここで，スクロール膨張機の膨 張過程を Fig. 1 に示す。膨張機内には，インボリュート曲線 で構成された固定スクロールおよび摇動スクロールが互いに 噛み合うように組み込まれている。Fig. 1のようにスクロール 中心部から給気された高圧の作動流体はスクロール壁面を押 し，摇動スクロールの回転運動を促す。スクロールの回転に 伴って形成された三日月状の膨張室は作動流体のエネルギに よって増大し，外周部へ移動する。この過程において，摇動 スクロールは固定スクロールと一定の偏心距離を保ちながら 旋回運動し，クランク軸を回転させ，流体の持つ内部エネル

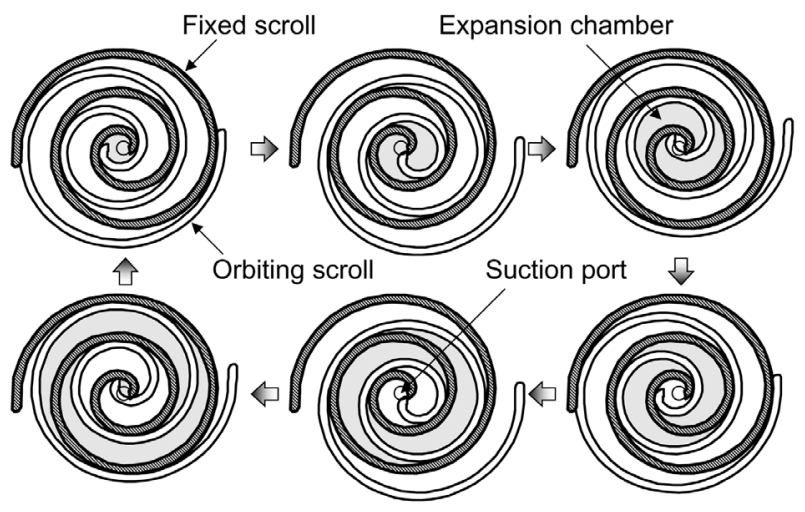

Fig. 1 Expansion process of scroll expander
ギを機械エネルギへ変換することが可能となる。

\section{2 スクロール膨張機の構造および漏れ防止機構}

本研究で用いたスクロール膨張機の構造を Fig. 2 に示す。 固定スクロールの中心部に給気口，上下 2 箇所に排気口が設 けられている。また，2.1節で述べた摇動スクロールの旋回運 動は Fig. 2 中および Fig. 3 の従動リンクによりクランク軸の 回転運動に変換される。

一対のスクロールによって形成される膨張室には, Fig. 2の ように軸方向および半径方向に隙間が存在する。軸方向隙間 はスクロール先端とそれに向かい合うスクロール底面間に， 半径方向隙間は両スクロール側面間に形成される。これらの 隙間からそれぞれ半径方向および周方向に作動流体の漏れが 発生し, 膨張機性能に大きな影響を与えるため, 漏れを低減 することが重要となってくる。

ここで軸方向隙間の詳細を Fig. 4 に示す。軸方向隙間の大 きさはスラスト軸受と固定スクロールの間に挟み込まれてい るシムの厚さで決まり，さらにスクロール歯の先端部にチッ プシールを取り付けることで半径方向への漏れを抑制してい る。一方，半径方向隙間の調節にはFig. 3に示した従動リンク を用いる。従動リンク機構は摇動スクロールの背面に組み込 まれており, 半径方向隙間の縮小ひいては油膜力の増加に寄 与し，漏れの低減を可能とする ${ }^{12)}$ 。しかし，従動リンクによ る漏れの抑制は摩擦の増大とトレードオフの関係にあり，己

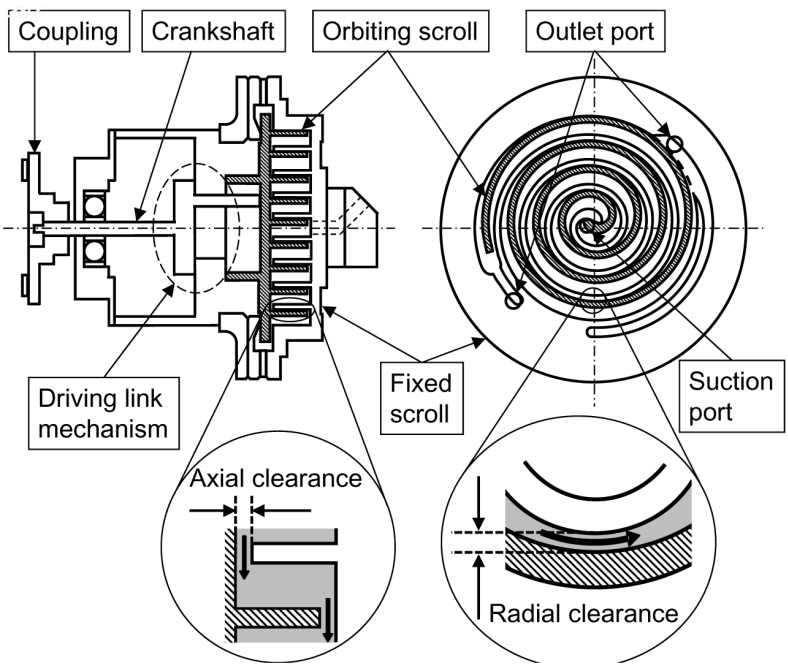

Fig. 2 Structure of scroll expander

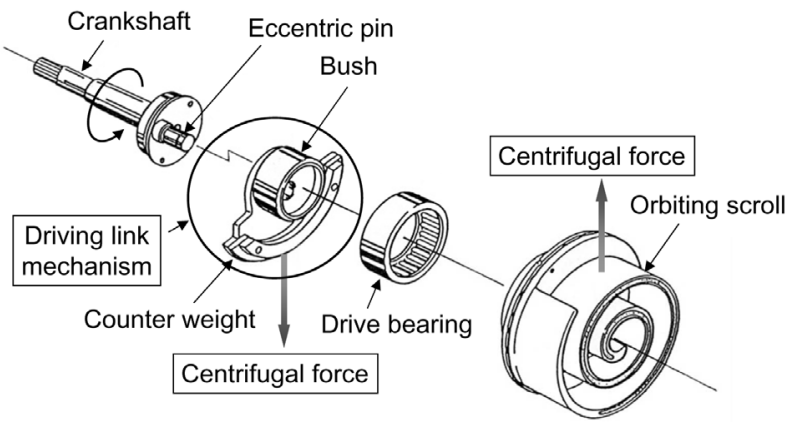

Fig. 3 Driving link mechanism 


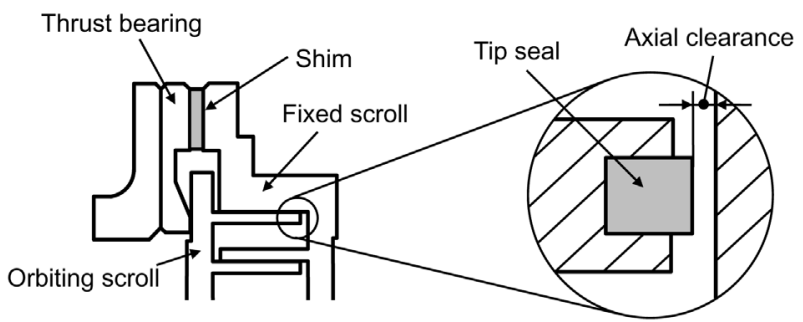

Fig. 4 Detail of axial clearance

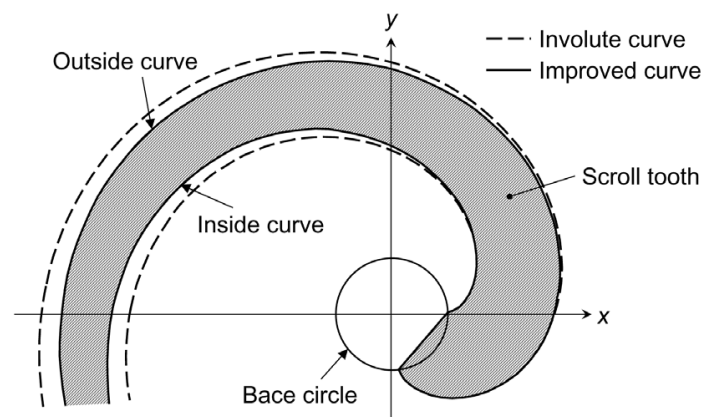

Fig. 5 Configuration of improved orbiting scroll

の方法による漏れへの対応には限度がある。また，周方向漏 れは作動流体が高圧である膨張過程初期において著しい。

このため, 本研究では Fig. 5 に示すように摇動スクロール の歯形形状を中央部ほど歯幅が厚くなるように改良し，スク ロール中央部に抢ける半径方向隙間を減少させることで膨張 過程初期に生じる内部漏れの低減を図った。改良歯形の理論 的詳細については 3.2 節に記す。

\section{3 膨張室における作動流体の圧力測定}

スクロール膨張機の膨張過程における熱流体損失，機械損 失の把握のためには，膨張室内における作動流体の圧力変化 を計測する必要がある。このため, 本研究では固定スクロー ルの底面に圧力七ンサ (Kulite, HEM形; 最大使用圧力 $1.7 \mathrm{MPa}$ ) を設置することで圧力計測を行なった。センサの設置位置を Fig. 6に示す。スクロール膨張機内には，給気が先に完了する 膨張室（早締め室）と遅れて完了する膨張室（遅締め室）が 対になって形成される。そのため，1箇所の圧力測定のみで は膨張過程全体の圧力変化を把握することはできない。そこ で, 各膨張室に最低 1 つの圧力センサが存在するよう計 8 個

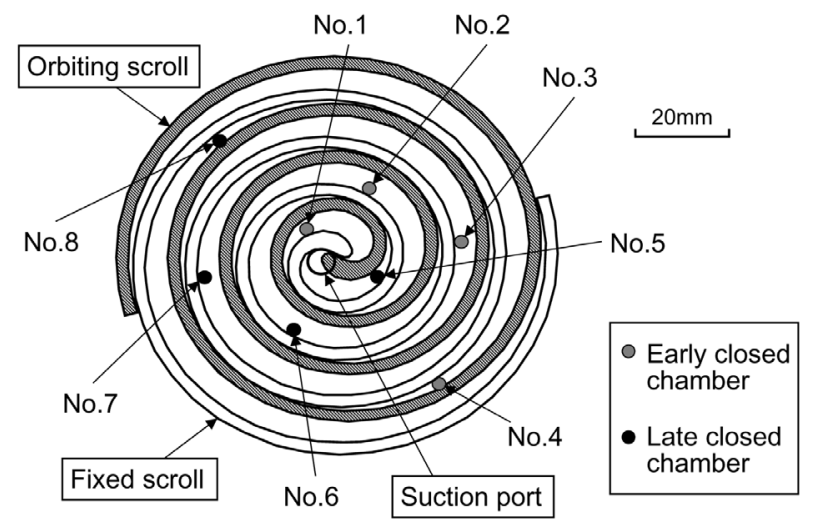

Fig. 6 Positions of pressure sensors in fixed scroll
の圧力センサを設置し, 内部圧力を計測した。各圧力センサ からの電圧出力は, チャージアンプで増幅しオシロスコープ に取り込む。早締め室, 遅締め室のそれぞれにおいて圧力セ ンサ 4 個分（早締め室：No.1 - 4，遅締め室：No.5 - 8) の波 形を重ね合わせることにより，連続した 1 つの圧力波形を描 くことができる。

\section{4 非対称スクロール}

従来の対称スクロールをFig. 7(a)に，本研究で新たに用い た非対称スクロールを（b）に示す。対称スクロールには早締 め室，遅締め室にそれぞれの排気口が設置され，両膨張室は 膨張過程において対称的な動作をなす。一方，非対称スクロー ルでは固定スクロールの歯形終端を $180 \mathrm{deg}$. 延長させ，膨張 機の排気口が 1 つとるように設計した。これにより対とな る膨張室は非対称的な動きを示すが，非対称型とすることで 遅締め室の膨張過程は早締め室より高膨張比となり，膨張機 体積を変えずに高出力化を図ることが可能となる。なお，摇 動スクロールは対称，非対称ともに共通の歯形を使用可能で ある。

\section{5 スクロール膨張機の性能試験装置}

実験装置のシステム概略図を Fig. 8 に示す。作動流体であ る水蒸気の供給源には電気式ボイラ (三浦工業, ME-50; モー 夕容量 $50 \mathrm{~kW}$, 最大蒸発量 $64 \mathrm{~kg} / \mathrm{h})$ を使用した。ボイラで高

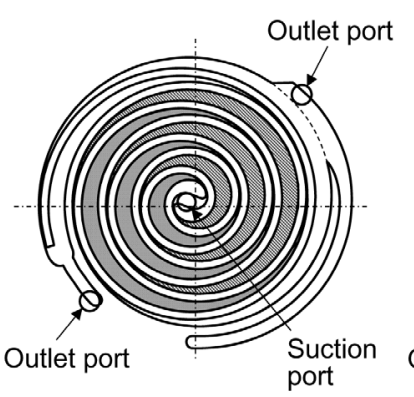

(a) Symmetric scroll

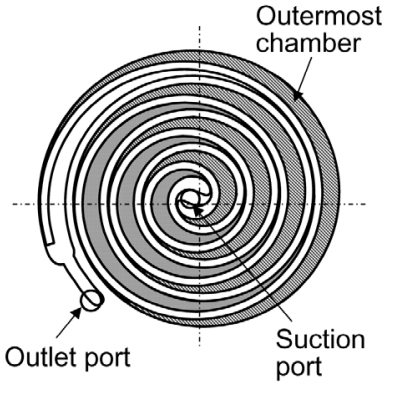

(b) Asymmetric scroll $\square$ Early closed chamber Late closed chamber

Fig. 7 Comparison of Symmetrical scroll with Asymmetric scroll

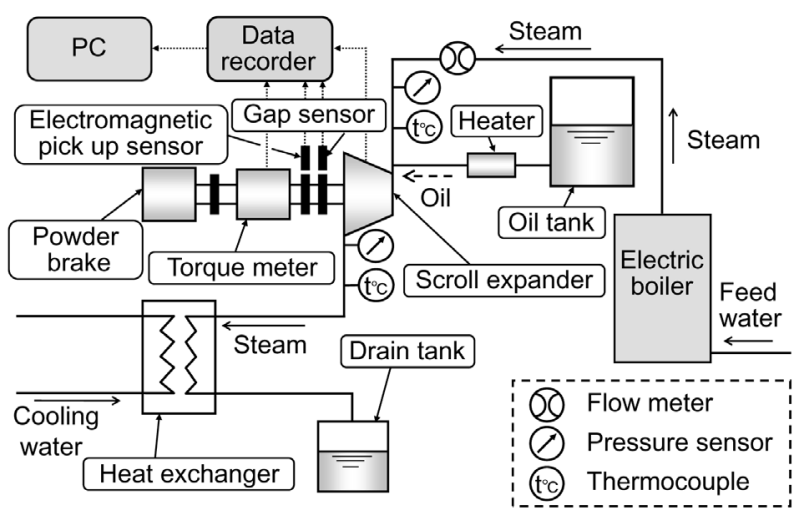

Fig. 8 Experimental apparatus for evaluation of scroll expander 
温・高圧となった水蒸気は, オイルタンクから別途供給され た潤滑油と混合し膨張機へと供給される。膨張機で仕事を行 なった水蒸気は熱交換器で凝縮し，ドレンタンクに排出され る。

スクロール膨張機に供給される作動流体の流量は, 膨張機 上流に設置した差圧式流量計（横河電機，EJA110 形；最大使 用圧力 $16 \mathrm{MPa}$, 計測許容差圧土 $100 \mathrm{kPa}$ ) で計測し, 膨張機 入口および出口には熱電対, 圧力計を設置する。膨張機への 負荷はパウダブレーキ (三菱電機, ZKB-5HBN; 定格トルク 50 $\mathrm{Nm}$ ) により制御し, 回転数を電磁ピックアップ (小野測器, MP-981), 軸トルクをトルクメータ (小野測器, SS-100) でそ れぞれ計測する。また, 膨張室内の圧力と膨張機の回転位置 との関係を把握するために, ギャップセンサにより回転位置 を測定している。これらの計測データはデータレコーダに記 録され，PCでの同時解析が可能である。

\section{3. スクロール膨張機の評価方法および理論}

\section{1 性能評価方法}

スクロール膨張機の性能評価には以下の解析 ${ }^{13)}$ を用いる。 容積形の流体機械であるスクロール膨張機は，流入した作動 流体を一旦給気室（最内室）に閉じ込めてから膨張を開始す る。このため, 作動流体の理想体積流量 $V_{t h}\left[\mathrm{~m}^{3} / \mathrm{s}\right]$ は次式で表 される。

$V_{\text {th }}=n V_{s}$

ここで, $n:$ 回転数 $\left[\mathrm{s}^{-1}\right], \mathrm{Vs}$ ：吸い込み容積 $\left[\mathrm{m}^{3}\right]$ である。

本膨張機では給気仕事，膨張仕事，排気仕事の和が仕事量 となるため, 理想仕事 $W_{t h}[\mathrm{~W}]$ は次式のように断熱膨張した際 の工業仕事

$$
W_{\text {th }}=\rho_{s} V_{f}\left(h_{s}-h_{d}\right)
$$

として表される。ここで $V_{f}$ : 水蒸気の実体積流量 $\left[\mathrm{m}^{3} / \mathrm{s}\right], \rho_{s}$ : 吸入水蒸気密度 $\left[\mathrm{kg} / \mathrm{m}^{3}\right], h_{\mathrm{s}}$ : 膨張機入口におけるエンタルピ $[\mathrm{J} / \mathrm{kg}] ， h_{d}$ : 排気圧力まで断熱膨張した時の膨張機出口におけ る水蒸気のエンタルピ $[\mathrm{J} / \mathrm{kg}]$ である。なお, 水蒸気の状態量 は物性計算プログラム REFPROP Ver.7.0 ${ }^{14)}$ により算出した。 また，図示仕事 $W_{i}[\mathrm{~W}]$ は以下の式で表される。

$W_{i}=n \cdot \oint P d V$

ここで, $P$ : 膨張室圧力 $[\mathrm{Pa}], V:$ 膨張室容積 $\left[\mathrm{m}^{3}\right]$ である。

さらに, 正味仕事 $W_{\exp }[\mathrm{W}]$ は正味トルク $\operatorname{Tr}_{\exp }[\mathrm{Nm}]$ を用いて 次式で表される。

$W_{\text {exp }}=2 \pi n \operatorname{Tr}_{\exp }$

理論仕事と図示仕事の差が熱や漏れ損失等の熱流体損失 $L e n$ [W]，図示仕事と正味仕事の差が軸受や摺動部等での摩擦に よる機械損失 $L_{m e}[\mathrm{~W}]$ となるため,

$$
\begin{aligned}
& L_{\text {en }}=W_{\text {th }}-W_{i} \\
& L_{\text {me }}=W_{i}-W_{\text {exp }}
\end{aligned}
$$

と表される。また，正味の膨張機効率 $\eta_{\exp }[-]$ を $\eta_{\exp }=W_{\exp } / W_{\text {th }}$

と定義し，これらを基に膨張機の性能評価を行なう。

\section{2 摇動スクロールの歯形改良}

2.2節で述べたように, スクロール膨張機の性能向上には最 内室から外側の膨張室へ生じる内部漏れの低減が必要となる。 そのため本研究では，インボリュート曲線で形成された歯形 に改良を施し，内部漏れの低減を図った。ここで，基礎円半 径 $a_{i}$ のインボリュート曲線 $(x, y)$ は，次式で表される。

$x=a_{i} \cos (t)+a_{i} t \sin (t)$

$y=-a_{i} \sin (t)+a_{i} t \cos (t)$

ただし， $t$ : 展開角 $[\mathrm{rad}]$ である。

本膨張機に使用した歯形形状は, Fig. 9に示すように展開角 の増加に伴って基礎円半径が変化する曲線である。曲線の開 始角度を $t_{s t}$ とし, そのときの基礎円半径を $a_{0}$ とすると, 曲線 の開始点 $X_{0}, Y_{0}$ は,

$$
\begin{aligned}
& X_{0}=a_{0} \cos \left(t_{s t}\right)+a_{0} t_{s t} \sin \left(t_{s t}\right) \\
& Y_{0}=-a_{0} \sin \left(t_{s t}\right)+a_{0} t_{s t} \cos \left(t_{s t}\right)
\end{aligned}
$$

で示される。また, 曲線の終了角をtend とし, そのときの基礎 円半径を $a_{1}$ とすると，展開角 $\mathrm{t}$ における基礎円半径 $a(t)$ は

$$
a(t)=a_{0}+\frac{t-t_{s t}}{t_{\text {end }}-t_{\text {st }}}\left(a_{1}-a_{0}\right)
$$

で表される。したがって，本膨張機の歯形曲線は

$$
\begin{aligned}
& X(t)=a(t) \cos (t)+L \sin (t) \\
& Y(t)=-a(t) \sin (t)+L \cos (t)
\end{aligned}
$$

で示される。ただし，Fig. 9に示すようにLは展開長さを表し， その増加量は次式で表される。

$$
\frac{d L}{d t}=a(t)
$$

前述のFig. 5のように, 本研究で用いた摇動スクロールの内 側曲線は展開角の増大に伴う基礎円半径の拡大により，イン ボリュート曲線よりも外側へ広がるように設計され，一方の 外側曲線は基礎円半径の縮小とともに内側へ寄るように設計 されている。すると摇動スクロールの歯幅は中央部で厚く, 外 周部ほど薄くなり, Fig. 2に示す各膨張室の半径方向隙間は中 心部に近いほど縮小する。このため，この設計は中心部にお ける油膜力の強化，ひいては漏れの抑制に有効となる。なお， 固定スクロールの歯形形状はインボリュート曲線で形成され ている。

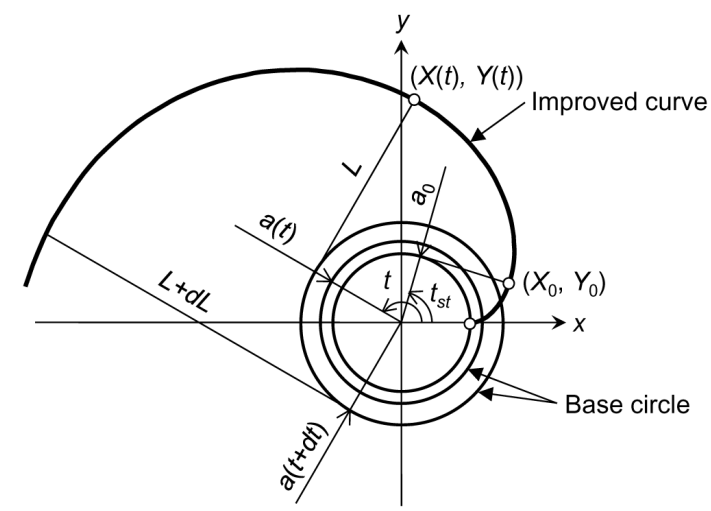

Fig. 9 Geometric curve of improved orbiting scroll 


\section{4. 実験結果および考察}

本研究の実験条件をTable 1に示す。以下において，摇動ス クロールの歯形がインボリュート曲線で形成された従来の膨 張機を膨張機 A，摇動スクロールの歯形を改良した場合を膨 張機 $\mathrm{B}$ ，膨張機を非対称型に組換えた上で歯形を改良した摇 動スクロールを用いた膨張機を膨張機 C と呼称する。

本章ではまず，上記 3 条件について膨張過程の圧力波形を 比較し，膨張機内に扔ける漏れ等の現象について考察する。そ の結果を踏まえ，膨張機効率，正味出力および膨張過程で生 じる損失を比較することで，歯形改良の効果および非対称入 クロールが膨張機性能に与える影響を検証する。

\section{1 膨張過程における漏れ特性の比較}

各膨張機の膨張過程における圧力変化を Fig. 10 に示す。 Fig. 10 の圧力波形は，膨張機内で対に形成される早締め室と 遅締め室における圧力の平均值を表している。軸の回転角 $\theta$ を横軸にとり， $\theta=0$ deg.の基準はFig. 11 に示したスクロー ルの位置とする。また， $\theta_{\mathrm{se}}=65 \mathrm{deg}$.は早締め室の， $\theta_{\mathrm{sl}}=127$ deg. は遅締め室の膨張開始時期であり， $\theta_{\mathrm{ss}}=82 \mathrm{deg}$. は中央 部の最内室形成およびその最内室への給気開始時期, そして $\theta_{e}=1096$ deg. は排気開始時期となる。なお，ここでは給気 圧力および回転数がそれぞれ $590 \mathrm{kPa}, 1800 \mathrm{rpm}$ の場合の波 形を示している。Fig. 10 より，各澎張機の圧力はいずれも理 想的な等エントロピー䐍張曲線よりも高い值で推移している ことが分かる。これは膨張過程において生じた膨張機内の漏 れが原因と考えられ，より圧力が高く推移している膨張機 $\mathrm{A}$ において漏れが顕著であると推定される。

\subsection{1 歯形改良が漏れ特性に及ぼす影響}

歯形改良の効果をより詳細に把握するため，膨張機 $\mathrm{A}$ およ び膨張機Bの早締め室，遅締め室における圧力変化を Fig. 12 に示し比較する。まず早締め室における波形では，膨張機A， B ともに早締め室の膨張開始時期 $\left(\theta_{\text {se }}=65 \mathrm{deg}\right.$. $)$ 以前から給 気時の圧力損失の影響による圧力低下が見られる。そして膨 張機 $\mathrm{A}$ の早締め室における波形を見ると, 最内室が形成され て給気の始まる $\theta_{\mathrm{ss}}=82 \mathrm{deg}$. 付近から $\theta=360 \mathrm{deg}$.にかけて 圧力降下が緩やかになっている。この原因は膨張機内におけ る漏れによるものと考えられ，高圧の最内室の形成によって 外側の膨張室への漏れが発生したと推測される。膨張過程中

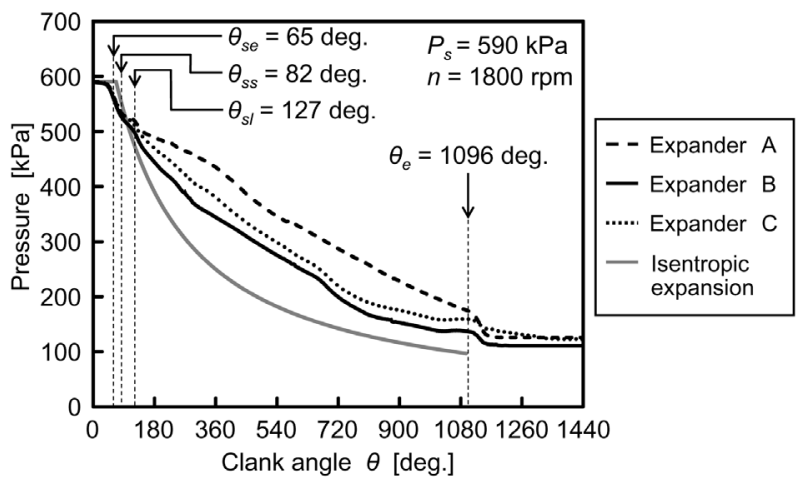

Fig. 10 Pressure diagram of scroll expander

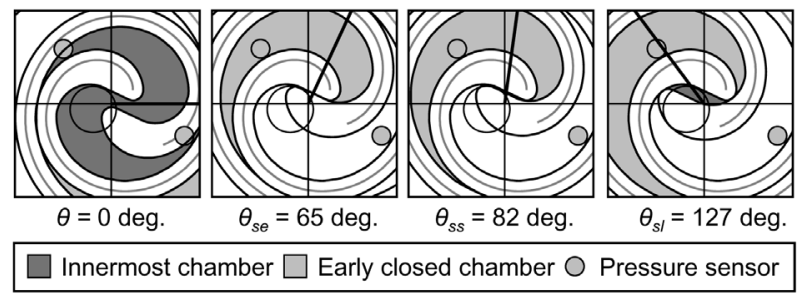

Fig. 11 Schematic structure of central region inside scroll expander

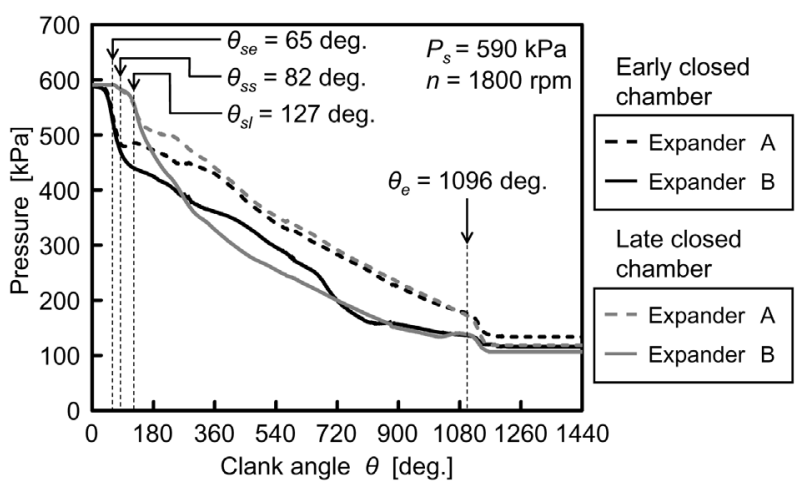

Fig. 12 Pressure diagram in early closed and late closed chamber of Expander A and B

盤以降はその影響が小さくなるため, 早締め室の圧力は遅締 め室の圧力と同等に変化する。

一方，膨張機 B の早締め室における波形を見ると，A と同 様に漏れの影響により $\theta_{\mathrm{ss}}=82 \mathrm{deg}$. 以降において波形の傾き が緩やかになるが，圧力は $\mathrm{A} よ り$ 低い值で推移している。こ れは漏れ量の違いに起因しており, 膨張機 Bでは中央部の半 径方向隙間が小さくなるように歯形を改良した効果によって,

Table 1 Experimental conditions

\begin{tabular}{|c|c|c|c|c|}
\hline \multicolumn{2}{|l|}{ Name of scroll expander } & $\begin{array}{c}\text { Expander } \\
\text { A }\end{array}$ & $\begin{array}{c}\text { Expander } \\
\text { B }\end{array}$ & $\begin{array}{c}\text { Expander } \\
\mathrm{C}\end{array}$ \\
\hline \multicolumn{2}{|c|}{ Type of scroll expander (fixed scroll) } & \multicolumn{2}{|c|}{ Symmetric } & Asymmetric \\
\hline \multicolumn{2}{|c|}{ Scroll profile of orbiting scroll } & Involute curve & \multicolumn{2}{|c|}{ Improved curve } \\
\hline \multicolumn{2}{|c|}{ Working fluid } & \multicolumn{3}{|c|}{ Steam } \\
\hline Suction pressure & {$[\mathrm{kPa}]$} & \multicolumn{3}{|c|}{590} \\
\hline Discharge pressure & {$[\mathrm{kPa}]$} & \multicolumn{3}{|c|}{101} \\
\hline Suction temperature & {$\left[{ }^{\circ} \mathrm{C}\right]$} & \multicolumn{3}{|c|}{158.2} \\
\hline Revolution speed & $n \quad[\mathrm{rpm}]$ & \multicolumn{3}{|c|}{$800-2100$} \\
\hline Quality of lubricant oil & $q_{\text {oil }}[\mathrm{L} / \mathrm{min}]$ & \multicolumn{3}{|c|}{0.06} \\
\hline
\end{tabular}


Aよりも漏れを抑制できたと考えられる。ただし，依然とし て漏れの影響が波形に見られるため，早締め室においてはま だ改善の余地があるといえる。

次に膨張機 $\mathrm{A}, \mathrm{B}$ の遅締め室に打ける波形に着目すると, 早 締め室と同様に圧力損失の影響により膨張開始 $\left(\theta_{s l}=127\right.$ deg.) 以前から圧力低下が生じている。そして, 膨張開始後し ばらくすると圧力変化に明らかな差異が見られる。膨張機 A の波形には起伏が見られ前述したような最内室からの漏れが 発生しているのに対し, 膨張機 B の遅締め室では起伏が一切 見られないことから，漏れを抑制できたことが分かる。以上 のように，歯形を改良した膨張機 B では早締め室，遅締め室 ともに漏れを抑制できており，特に遅締め室においては高い 効果が得られた。

\subsection{2 非対称スクロールが漏れ特性に及ぼす影響}

非対称スクロール膨張機の漏れ特性を把握するため，膨張 機 $\mathrm{B}$ および膨張機 $\mathrm{C}$ の早締め室，遅締め室における圧力変化 を Fig. 13 に示し比較する。

脵張機 $\mathrm{C}$ の早締め室における波形では $\theta_{s s}=82 \mathrm{deg}$. のしば らく後から $\theta=180 \mathrm{deg}$. 付近においてBより圧力降下が緩や かになり, 中盤以降はB，Cともにほほ同様の圧力変化となる。 前半に膨張機 C の圧力が高く推移する原因は，前節で述べた A の場合と同様に最内室からの漏れ込みによるものと考えら れる。すなわち，半径方向隙間を介した最内室からの漏れ込 みは歯形を改良した膨張機 Bにおいて抑制できたものの，非 対称スクロールに組換えた膨張機 Cでは再び増加したことに なる。非対称スクロールでは高膨張比化のため遅締め室の膨 張行程が早締め室より $180 \mathrm{deg}$. だけ長く, Fig. 13 に示す通り 遅締め室の排気開始角度は $\theta e^{\prime}=1276$ deg. となる。その影響 により，対称スクロールでは保たれていた早締め室と遅締め 室から得られるトルクのバランスが不安定となり, 中央部の 半径方向シール力が弱まることで漏れの増加につながったと 考えられる。また，排気圧力に着目すると，膨張機 C の早締 め室では B に比べて排気圧力が高く，不足膨張が促進されて いる。不足膨張が生じると作動流体は膨張しきらないまま排 気され，流体のもつエネルギを未回収のまま捨てることにな るため，エネルギ損失の一因となる。

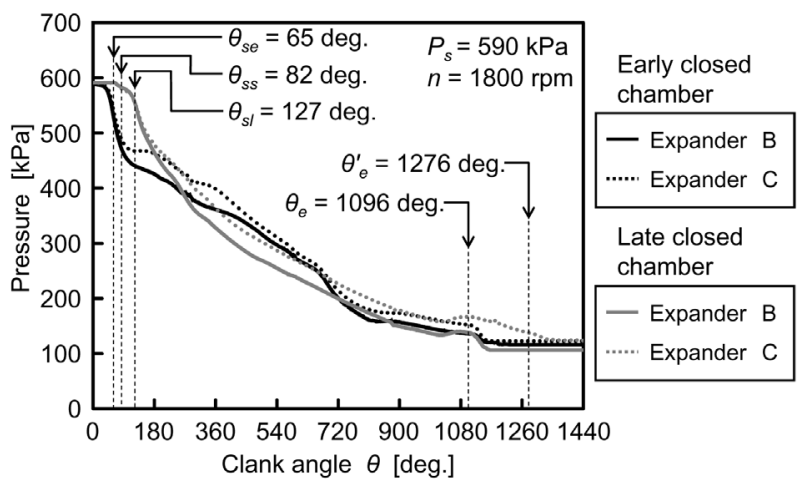

Fig. 13 Pressure diagram in early closed and late closed chamber of Expander $B$ and $C$
次に膨張機 $\mathrm{B}, \mathrm{C}$ の遅締め室における圧力波形を比較する と，Cの波形の方が全体的に高めに推移する。膨張機 Cでは 遅締め室を高膨張比にしたことで固定, 摇動スクロールの接 触点が増えたため，各膨張室の圧力が高くなると考えられる。 終盤まではB，Cともに滑らかな曲線となっており，早締め室 のような大きな漏れは見られない。また，それぞれの排気開 始時 $\theta_{e}, \theta e$ に损ける圧力に着目すると, やや不足膨張の傾 向が見られるもののいずれも同等の排気圧力であるため，作 動流体から得られる仕事量 (図示仕事) はBよりCの方が大 きいと判断できる。

\section{2 膨張機性能の比較}

本節では4.1節の内容を踏まえた上で，歯形改良前後および 非対称スクロール組換え時における水蒸気流量や効率, 損失 など膨張機性能の比較を行なった。なお，いずれの比較にお いても膨張機の回転数を横軸にとったグラフで整理した。

\section{2 .1 水蒸気流量の比較}

各膨張機に供給した水蒸気流量をFig. 14に示す。本研究で はいずれの膨張機も膨張機容量および給気圧力は一定である ため，同じ回転数において見られる流量の差は膨張過程で生 じた損失，特に漏れ損失の差異として表れる。Fig. 14の通り， 膨張機 $\mathrm{B}$ と $\mathrm{C}$ における水蒸気流量は $\mathrm{A}$ に比べ格段に少なくな り，4.1節で考察した歯形改良による漏れ低減効果が裏付けら れる結果となった。また，非対称スクロールである膨張機Cの 流量はBに比べ僅かに多く，4.1.2 項で述べた通り遅締め室の 高膨張比化によるトルクバランスの不安定化に起因した，早 締め室での漏れの微増が原因と考えられる。

\subsection{2 正味出力および膨張機効率の比較}

各膨張機における正味出力および膨張機効率をFig. 15, 16 に示す。正味出力はどの膨張機も高回転になるにつれ直線的 に増加しており，その值を比較すると膨張機 $\mathrm{A} か ゙$ 最も高くC, B と続く。一方で Fig. 16 の膨張機効率では高回転になるにつ れ増加傾向が緩やかになっており，その值は膨張機 $\mathrm{A} か ゙$ 最も 低くCが最高值を示す。前述の通り Aでは B，Cに比べて供給 された水蒸気流量，すなわち投入エネルギが格段に多いため に，出力として大きな動力エネルギが回収できたと考えられ

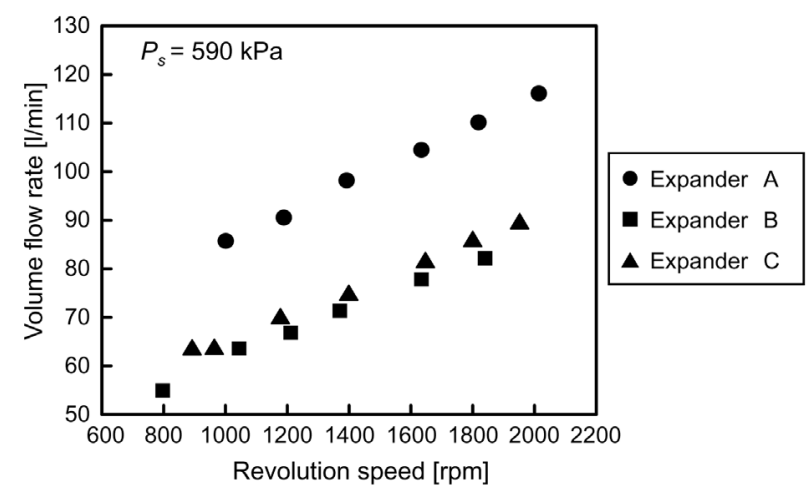

Fig. 14 Effects of revolution speed on volume flow rate 


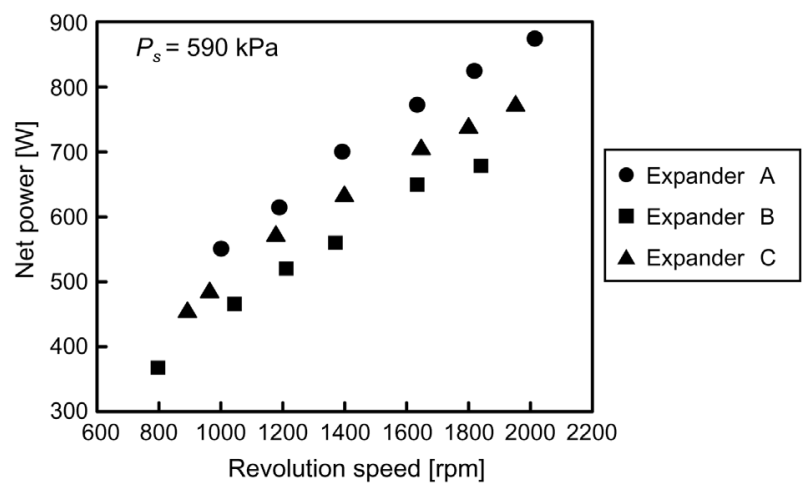

Fig. 15 Effects of revolution speed on net power output

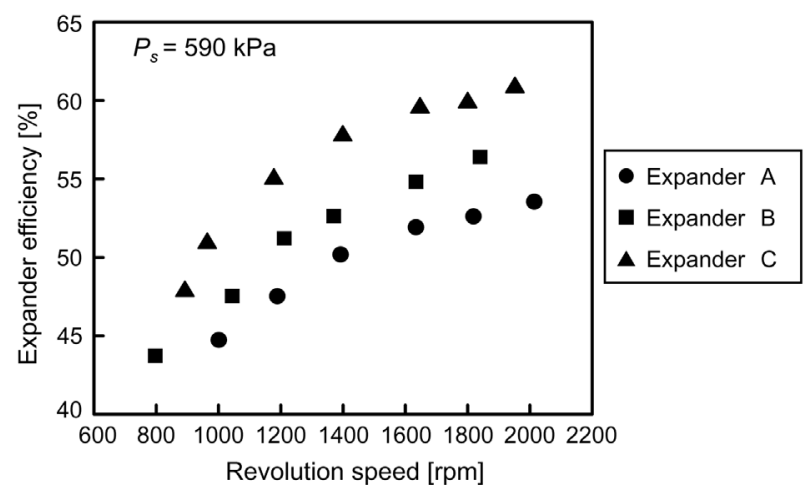

Fig. 16 Effects of revolution speed on expander efficiency

る。しかし，本研究では3.1節で述べたように，膨張機に供給 した水蒸気流量を基に理想出力を算出し膨張機効率を求める ため，効率の最も低い膨張機 $\mathrm{A}$ は水蒸気流量に見合う出力を 効率的に取り出せなかったといえる。逆に膨張機B，Cでは出 力こそ $\mathrm{A} に$ 劣るものの，漏れを減らし水蒸気流量を抑制でき たために膨張機効率が A から飛躍的に向上し，膨張機 $\mathrm{C}$ の効 率は回転数1950 rpmに㧍いて最高の值60.8\%を示した。また， 遅締め室の高膨張比化により高出力化が可能となり，非対称 スクロールである膨張機 C の正味出力は対称型の B に比べ約 12\%向上した。

\subsection{3 熱流体損失および機械損失の比較}

各膨張機における熱流体損失および機械損失をFig. 17に示 す。まず熱流体損失に着目すると，膨張機B，Cは互いにほぼ 同等となり，その值は $\mathrm{A} の$ 約 $1 / 2 \sim 2 / 3$ 以下にまで抑制でき ている。この差は漏れ損失に起因しており，これまで考察し てきたように歯形改良を施した膨張機B，Cでは漏れの大幅な 低減に成功したことを意味する。また，膨張機B，Cの熱流体 損失がほぼ同等の值となった理由は，4.1.2項や4.2.1項におい て述べたように，非対称スクロールに組換えた影響により膨 張機 $\mathrm{C}$ の早締め室において漏れの微増を招いたものの，遅締 め室では図示出力ひいては正味出力の向上につながり，それ らの効果が相殺されたためと考えられる。

次に機械損失に着目すると，どの膨張機においてもその值 はほぼ同等であり，高回転になるにつれ増大する。この結果 から，歯形改良および非対称スクロールへの組換えは機械損

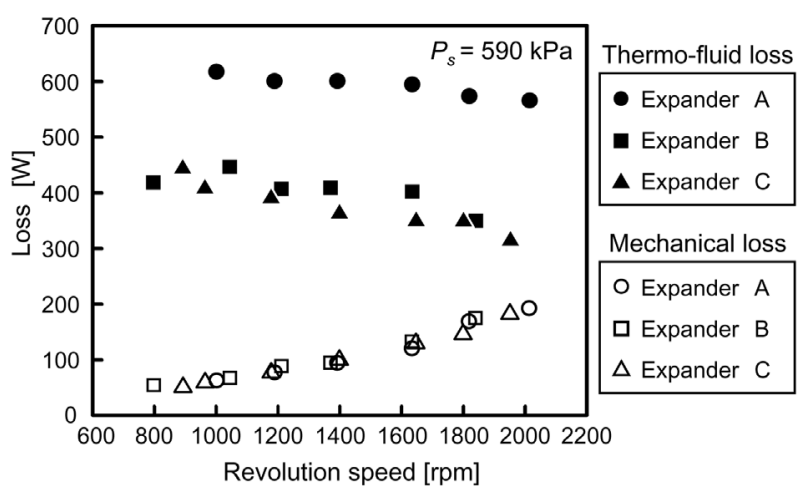

Fig. 17 Effects of revolution speed on thermo-fluid loss and mechanical loss

失にほとんど影響せず，高回転域においては機械損失の主要 因である摩擦損失の影響を軽視できなくなる。機械損失の影 響はFig. 16の膨張機効率にも表れており，高回転における効 率の増加傾向の緩和は機械損失の増大が主因である。

\section{3 システム評価および今後の展望}

過去の研究において行なった $12.5 \mathrm{~kW}$ 単気筒小型ディーゼ ルエンジン (ヤンマー, NF-19) を対象としたサイクルシミュ レーション3)の結果によると，膨張機効率が $50 \%$ に達するこ とで，エンジン排熱から約 $1.0 \mathrm{~kW}$ の動力が回収可能となり, 対象エンジンの出力を約 8 \% 向上できると見込まれている。 そして，本研究における膨張機効率の最高值は膨張機 $\mathrm{C}$ の条 件において $60.8 \%$ を示しており，スクロール膨張機が小規模 ランキンサイクルによる排熱回収発電システム用の動力回収 機として十分に有効であることが確認できた。ただし，本膨 張機はまだ改良の余地が残されている段階であり，早締め室 における漏れの抑制および機械損失の低減等に向けた対策が 必要と考える。これらの課題に対応することで膨張機の更な る性能向上が可能となり，本システムの最適化抒よび実用化 がより一層期待できる。

\section{5. 結 言}

本研究ではスクロール膨張機の性能向上を目的に，スク ロール歯形形状の改良および非対称スクロール膨張機の性能 試験を行ない，以下に示す知見を得た。

（1）スクロール歯形形状の改良により，膨張過程初期に生じる 最内室からの内部漏れを大幅に抑制できる。

（2）歯形を改良した膨張機では，機械損失を増大させることな く熱流体損失を改良前の $2 / 3$ 以下に抑制可能となる。

(3) 歯形改良を施した非対称スクロール膨張機では高膨張比化 により，歯形改良のみの場合に比べ損失を増大させること なく正味出力を約 $12 \%$ 向上し得る。

(4) 膨張機効率は，歯形を改良した膨張機では従来の膨張機よ り約 6〜 7\%改善でき，さらに非対称スクロールに組換え ることで歯形改良のみの場合より約 $7 \sim 9 \%$ 向上する。こ れにより，歯形改良を施した非対称スクロール膨張機の効 率は回転数 $1950 \mathrm{rpm}$ において最高で $60.8 \%$ に達する。 


\section{謝 辞}

本研究の一部は, 文部科学省-私立大学戦略的研究基盤形成 支援事業「ゼロエミッション技術を基盤とした環境調和型工 ネルギーグリッドの最適化 (S0901038: 平成 21-25 年度)」の 支援により行なわれた。ここに記して謝意を表する。

\section{文 献：References}

1) 田中洋一, 日エ市誌，88(8)，738-742(2009) : Tanaka, Y, J. Jpn. Inst. Energy, 88 (8)， 738-742(2009)

2）川端裕二，奥本和史，高良伸治，阿部幸介，千田二郎，千 田衞，日工市誌，86(6)，411-417(2007) : Kawabata, Y., Okumoto K., Takara S., Abe, K., Senda, J., Senda, M., J. Jpn. Inst. Energy, 86 (6), 411-417(2007)

3）奥本和史，川端裕二，高橋秀行，高良伸治，阿部幸介，演 地康之, 小野泰右, 千田二郎, 千田衞, 日本機械学会論文 集B編，73(735)，2311-2316(2007)：Okumoto K., Kawabata, Y., Takahashi, H., Takara S., Abe, K., Hamachi Y., Ono T., Senda, J., Senda, M., Transactions of the Japan Society of Mechanical Engineers Series B, 73 (735), 2311-2316 (2007)

4）柳沢正, 清水孝, 福田充宏, 半田友久, 日本機械学会論文 集B編，54 (506)，2798-2803(1988)：Yanagisawa T., Shimizu T., Fukuta M. and Handa T., Transactions of the Japan Society of Mechanical Engineers Series B, 54 (506), 2798-2803 (1988)

5) Lemort V., Quoilin S., Cuevas C., Lebrun J., Thermal Engineering, 29, 3094-3102 (2009)

6）川端裕二，奥本和史，高橋秀行，高良伸治，阿部幸介，演 地康之, 小野泰右, 千田二郎, 千田衞, 日本機械学会論文 集B編，73(735)，2317-2322(2007)：Kawabata, Y., Okumoto K., Takahashi H., Takara S., Abe, K., Hamachi Y., Ono T., Senda, J., Senda, M., Transactions of the Japan Society of
Mechanical Engineers Series B, 73(735), 2317-2322(2007)

7）平野隆久, 萩本清, 前田光敏, 冷論, 8 (1), 53-64 (1991) : Hirano, T., Hagimoto, K., Maeda, M., Trans. JAR, 8 (1), 53-64(1991)

8）香曽我部弘勝, 竹林昌寛, 功刀能文, 大嶋靖浩, 畠裕章, 冷論, 11 (3)，337-347(1994): Kohsokabe, H., Takebayashi, M., Kunugi, Y., Ohshima, Y., Hata, H., Trans. JAR, 11 (3), 337-347 (1994)

9）小川博史, 内田和秀, 宇野慶一, 自動車技術会学術講演会 前刷集，No. 66-06 (2006)：Ogawa H., Uchida K., Uno K., JSAE Convention Proceedings, No. 66-06 (2006)

10）李丙哲, 柳沢正, 李東洙, 趙洋熙, 日本機械学会論文集C 編，68(672)，2286-2292 (2002)：Lee, B., Yanagisawa T., Lee D., Cho Y., Transactions of the Japan Society of Mechanical Engineers Series C, 68 (672), 2286-2292(2002)

11）土屋豪，藤村和幸，柳瀬裕一，松永睦憲，中村総，太田原 優，冷空講論，11(3)，337-347(1994)：Tsuchiya T., Fujimura K., Yanagase Y., Matsunaga M., Nakamura S., Ohtawara M., Proceedings of (1994) JSRAE Annual Conference, 11 (3), 337-347 (1994)

12）平賀正治，榊正勝，清水茂美，真部淳，塚越康弘，寺内 清，冷凍，62(720)，1106-1115(1987)：Hiraga, M., Sakaki M., Shimizu S., Mabe A., Tsukagoshi T., Terauchi K., Refrigeration, 62(720), 1106-1115(1987)

13）長友繁美，大高敏男，森嶋明，冷空論，16(2)，123-132 (1999) : Nagatomo, S., Ootaka, T., Morishima, A., Trans. JSRAE, 16 (2), 123-132(1999)

14) NIST Reference Fluid Thermodynamic and Transport Properties Database (REFPROP) Version7.0, U. S. Department of Commerce, Maryland, (2002) 